\title{
Die verskille tussen Koue Oorlog en post-Koue Oorlog strategiese denke
}

\author{
Abel Esterhuyse ${ }^{\bullet}$
}

\section{Inleiding}

Hierdie artikel het ten doel om die belangrikste verskille in strategiese denke tydens die Koue Oorlog en post-Koue Oorlog uit te lig. Die bespreking word gedoen teen die agtergrond van wat Brzezinski ${ }^{1}$ beskryf as 'the three grand transformations' van hierdie eeu. Die eerste transformasie is deur die ineenstorting van die magsbalans in Europa en die beeïndiging van Europa se bepalende geo-politieke posisie in die wêreld, teweeg gebring. Die 'Eerste Wêreldoorlog' was in wese die laaste Europese oorlog wat deur belangrike globale Europese (koloniale) moondhede geveg is. Dit het op 'n poging uitgeloop om Europa, en indirek die res van die wêreld, op 'n nuwe beginsel te organiseer: die oppergesag van die nasiestaat. Deur nasionalisme het hierdie beginsel nuwe stukrag aan politieke emosie verleen. Dit het gevolglik nie daarin kon slaag om internasionale veiligheid te verseker nie.

Die einde van die Tweede Wêreldoorlog het 'n einde gemaak aan Europa se sentrale posisie in wêreldpolitiek. Europa het eerder die kritiese teater van globale kompetisie tussen twee nie-Europese moondhede geword. Die tweede transformasie sou, net soos die eerste, nie daarin slaag om internasionale veiligheid daar te stel nie. ${ }^{2}$ Die 45 jarige konflik tussen die supermoondhede wat gevolg het, het geweldige risiko's tot gevolg gehad. Ideologiese tweestryd tussen die supermoondhede het die wapenwedloop ge-intensifiseer, teen 'n geweldige ekonomiese koste, tot die ontwikkeling van wapens met 'n globale verwoestingspotensiaal. Die VSA kon egter daarin slaag om te voorkom dat die Sowjet-Unie die oorhand in Eurasië verkry. Ook was die VSA suksesvol om die Sowjet-Unie ideologies te diskrediteer en ekonomies uit te put. Die tweede transformasie is uiteindelik sonder 'n sogenaamde 'hot war' beeïndig.

Die derde transformasie het weereens tot fundamentele veranderinge in wêreldaangeleenthede gelei, terwyl dit na 'n dekade duidelik is dat hierdie transformasie ook nie tot internasionale veiligheid aanleiding gegee het nie. ${ }^{3}$ Wêreldwyd het dit tot geo-strategiese veranderinge aanleiding gegee. Die hereniging van Duitsland, die disintegrasie van die voormalige Sowjet-Unie en Joego-Slawië, asook hernieude streeksdinamika in baie dele van die wêreld, is enkele voorbeelde in die verband. Ook het dit filosofiese veranderinge tot gevolg gehad: die filosofiese gees van die huidige era word deur die Westerse konsepte van demokrasie en 'n vryemark-ekonomie oorheers.

Waar die eerste transformasie deur nasionalistiese aspirasies in Europa aangevuur is, was die grondslag van die tweede 'n ideologiese globale stryd tussen twee nieEuropese supermoondhede. Die strukture en gees van die derde transformasie is en word hoofsaaklik deur die politieke en filosofiese invloed van die suksesvolle Westerse-koalsie

\footnotetext{
Vakgroep Militêre Strategie, Fakulteit Krygskunde, Universiteit Stellenbosch. Scientia Militaria 31(1) 


\section{Esterhuyse}

gevorm. Hierdie aspekte vorm die onderliggende grondslag van strategiese denke in die onderskeie eras.

\section{Die bestaan van strategiese teorie}

'n Bespreking van hierdie aard sal nie volledige wees sonder 'n begrip van die rol en aard van strategiese teorie nie. Dit word vereis ten einde die bespreking te fokus. Wat die rol van strategiese teorie betref, is daar waarskynlik geen beter verduideliking daarvoor as wat deur Clausewitz voorgehou word nie. Clausewitz verduidelik die rol van (strategiese) teorie soos volg:

"Theory cannot equip the mind with formulas for solving problems, nor can it mark the narrow path on which the sole solution is supposed to lie by planting a hedge of principles on either side. But it can give the mind insight into the great mass of phenomena and of their relationships, then leave it free to rise into the higher realms of action." 4

In samehang hiermee onderskei Gray ${ }^{5}$ tussen vier vlakke van strategiese teorie. Die eerste vlak is teorie wat toepaslik is ongeag die tyd, politiek en sosiale omstandighede èn aard van tegnologie wat beskikbaar is. In hierdie opsig is dit in die post-Koue Oorlog-era veral belangrik om kennis te neem van die verband tussen tegnologie en strategie. Die geskiedenis toon aan dat ontwikkelinge in strategiese denke baie nou gekoppel is aan tegnologie. ${ }^{6}$ Tegnologie bepaal egter nie die aard en wese van strategie nie, maar slegs hoe strategie tydens 'n spesifieke periode beslag kry. Clausewitz en Sun Tzu se werke is tiperend van strategiese denke op hierdie vlak. Die tweede vlak verduidelik hoe die geografiese en funksionele kompleksiteit van oorlog en konflik met strategie in interaksie is en mekaar komplimenteer. Werke soos die van Beaufre, Liddell Hart en Corbett sal waarskynlik in hierdie kategorie geplaas kan word. Die derde vlak verduidelik hoe 'n spesifieke tipe militêre mag en die gebruik daarvan, die verloop van 'n konflik in geheel affekteer. Die werke van teoretici soos Mahan en Douhet, met hul onderskeie fokus op maritieme mag en lugkrag, kan in hierdie kategorie geplaas word. Die laaste vlak van strategiese teorie verduidelik die aard van konflik of oorlog in 'n spesifieke era, gekoppel aan eksplisiete aannames rakende die vermoëns van verskillende tipes mag en die voorwaardes vir die effektiewe aanwending daarvan tydens daardie era. Dit sluit algemene denke in wat daarop fokus om 'n verduideliking te vind vir die bydrae van 'n spesifieke magsinstrument om 'n strategiese effek in 'n spesifieke era daar te stel. Dit is duidelik dat 'n vergelyking van strategiese denke tydens die Koue en post-Koue Oorlog-era op hierdie vlak tuis hoort.

\section{Faktore wat strategiese denke tydens die Koue Oorlog bëivloed het}

Die Tweede Wêreldoorlog het twee fundamentele veranderinge tot gevolg gehad wat die aard van strategiese denke tydens die Koue Oorlog beïnvloed het. Eerstens was dit nie meer moontlik om die veiligheid van een kontinent onafhanklik van 'n ander te oorweeg nie. Veral Europa het tot 'n groot mate vir sy veiligheid van die VSA, maar ook die Sowjet-Unie, afhanklik geraak. Die totstandkoming van NAVO het hierdie realiteit geformaliseer. Die Tweede Wêreldoorlog het tweedens daartoe gelei dat dit nie meer moontlik was om die aanwending van die verskillende magsinstrumente onafhanklik van 


\section{Strategiese denke}

mekaar te oorweeg nie. Veral binne militêre verband was dit nie meer moontlik om die operasies van leërs onafhanklik van lugmagte en selfs vlote te oorweeg nie. ${ }^{8}$

Voorts het die gebruik van kernwapens aan die einde van die Tweede Wêreldoorlog verreikende gevolge vir die aard van strategiese denke gehad. Die problematiek van kernwapens en die gepaardgaande Koue Oorlog het vir die eerste keer burgerlikes by aangeleenthede betrek wat voorheen uitsluitlik die terrein van die militêr professie was. In hierdie verband was dit veral wetenskaplikes wat betrokke geraak by strategiese aangeleenthede en denke, hoofsaaklik weens hul rol in die ontwikkeling van hierdie wapens en die kritiese rol wat tegnologie in die handhawing van die militêre magsbalans tydens hier era gespeel het. Tesame hiermee het die bestaan van kernwapens besluitnemers gedwing om meer fondse beskikbaar te stel vir die bestudeer van streeksen internasionale verhoudinge en strategiese studies in 'n poging om faktore wat tot kernoorlog kon aanleiding gee, te identifiseer. Ook het die wese van strategiese studies tydens hierdie era verander. Net soos burgerlikes betrek is by strategiese studies, was dit ook nie langer tot die militêre professie en die effektiewe voer van oorlog beperk nie. Strategiese studies het tydens hierdie era meer abstrak, spekulatief en vooruitskouend van aard geword, gekenmerk deur 'n hoë tegniese kwaliteit. ${ }^{9}$

Ten einde die aard van strategiese denke tydens die Koue Oorlog in konteks te plaas, moet die aard van die bedreiging verstaan word. Die Sowjet-Unie met sy kommunistiese ideologie en sosialistiese regeringstelsel is as die allesoorheersende bedreiging beskou. Alle strategiese denke rakende bedreigings en hoe om dit teen te staan, is geprojekteer op die magsverhouding tussen die kommunistiese en sosialistiese 'Oosblok' en die demokratiese kapitalistiese 'Weste'. Dit is belangrik om hierdie aspek ook binne 'n bepaalde konteks te plaas. Thatcher beskryf dit soos volg:

"During the Cold War, we were in the rare situation of having to deal with a single adversary whom we came to know, one whose reactions and behavior we could often anticipate, and with whom we could usually communicate effectively."10

Die realiteit vanuit die oogpunt van strategiese studies was ' $n$ duidelik identifiseerbare bedreiging waarop alle energie an aandag gefokus kon word. Die VSA se vertrekpunt in die bekamping van hierdie bedreiging was die beleid van indamming (containment). ${ }^{11}$ Brodie $^{12}$ wys daarop dat alle optrede deur Westerse moondhede tydens die Koue Oorlog deur twee slagspreke geregverdig is: “(a) we must contain Communism, and (b) we must oppose or resist aggression occuring anywhere." Met 'n duidelik geïdentifiseer bedreiging en ' $n$ beleid van indamming as riglyn, het strategiese denke meestal gefokus op die middele waarmee en wyses waarop hierdie bedreiging teengestaan kon word. In wese het dit beteken dat die verdere uitbreiding van kommunisme ten alle koste voorkom moes word. Dit het strategiese denke tydens die Koue Oorlog enersyds baie tegnies en tegnologies van aard gemaak. Andersyds het dit 'n baie duidelike en spesifieke fokus gehad.

\section{Die aard van strategiese denke tydens die Koue Oorlog}

Strategiese denke tydens die Koue Oorlog was veral op drie aspekte gefokus:

- Kernwapens; 
- Insurgensie en teen-insurgensie;

- Beperkte Oorlog.

Die bestaan, besit en moontlike gebruik van kernwapens het strategiese studies tot 'n groot mate tydens die Koue Oorlog-era oorheers. Die Koreaanse Oorlog het 'n tradisie van nie-gebruik van kernwapens geskep. Die idee dat die waarde of nut van kernwapens geleë is in hul besit en nie in hul gebruik nie, het na vore gekom: "their purpose was not to conduct war but to maintain peace." 13 Hierdie is die onderliggende idee tot die konsep van afskrikking. Afskrikking is volgens Williams "14 "an attempt to frighten the adversary into inaction." Die verskillende kernstrategieë wat tydens die Koue Oorlog na vore gekom het, het die konsep van afskrikking as gemene deler gehad. In wese het die verskillende kernstrategieë denke verteenwoordig rakende welke wyse afskrikking geoptimaliseer kon word. Vir kernafskrikking om suksesvol te wees, moes daar egter 'n kernvermoë bestaan. Dit moes vergesel word van 'n geloofwaardige oortuiging by die opponent van die voorneme om hierdie wapens te gebruik. ${ }^{15}$ Dit is juis hierdie voortdurende moontlikheid van 'n kernoorlog wat aan die Koue Oorlog sy naam besorg het!

In teenstelling met die oorheersing van Eerste Wêreldveiligheid deur kernwapens, het die gevolge van die eerste transformasie, met sy klem op die belangrikheid van die nasiestaat, tesame met Europa se degenerasie in internasionaal politieke terme, tot dekolonisasie in die nie-Europese wêreld aanleiding gegee. Hierdie proses van dekolonisasie het in baie gevalle met die pyn van 'n insurgensie- en teen-insurgensiestryd gepaard gegaan, teen die agtergrond van die ideolodiese kompetisie tussen die supermoondhede. Denke rakende rewolusionêre oorlog, rewolusies, terrorisme, burgeroorlog, maar veral insurgensie en teen-insurgensie, was aan die orde van die dag. Die werke van McCuen en Thompson was enkeles wat 'n belangrike rol in hierdie verband vervul het. ${ }^{16}$ Margaret Thatcher $^{17}$, voormalige Britse Eerste Minister, verduidelik hierdie dimensie van die ideologies kompetisie soos volg:

"(A)lthough the Soviet leadership remain faithful to an expansionist ideology until the end, it was mostly . . . not adventurous. It preferred to pursue its aims through support for proxy forces or terrorists and through low-intensity conflict by means of subversion, propaganda, and disinformation."

Waarskynlik in reaksie en in samehang met die bestaan en denke rakende kernwapens en hul vernietigende aard, was daar ook weer 'n hernieude belangstelling in die idee van die beperking van oorlog. Denke rakende beperkte oorlog het veral na die VSA se beperkend benadering in die Koreaanse Oorlog, beslag gekry. ${ }^{18}$ Dit is egter gesteun deur die latere idee van eskalasie as 'n maatreël om 'n volskaalse kernoorlog te voorkom. Garnette ${ }^{19}$ wys daarop dat denke rakende beperkte oorlog om twee redes tydens die Koue Oorlog weer na vore gekom het. Eerstens het beperkte oorlog konvensioneel van aard - 'n alternatief verskaf vir die vernietiging van kernoorlog. In hierdie opsig was beperkte oorlog 'n alternatief vir kernafskrikking. Tweedens het baie geglo dat die vermoë om beperkte oorlog te voer, kernafskrikking versterk. Die idee van 'n beperkte oorlog was gevolglik aanvaarbaar vir beide diegene wat oorlog op 'n beperkte wyse wou veg èn die wat oorlog wou vermy. 


\section{Faktore wat strategiese denke in die post-Koue Oorlog-era bëivloed}

Daar is verskeie onderliggende faktore wat die aard van strategiese denke in die post-Koue Oorlog-era onderlê. Uiteraard word strategiese denke en die aard van die strategiese-agenda in die post-Koue Oorlog-era, net soos tydens die Koue Oorlog, bepaal deur die aard van die internasionale sisteem op die gegewe tydstip. Die eerste uitstaande aspek wat strategiese denkers in die post-Koue oorlog-era beinvloed, is die kompleksiteit van die internasionale omgewing. $\mathrm{Keel}^{20}$ beklemtoon byvoorbeeld dat "the post-cold-war strategic conceptual environment is much more complex and interdependent than any that our present leaders have faced before." Hierdie kompleksiteit word aan verskeie faktore toegeskryf. Die kompleksiteit daarvan blyk duidelik uit verskillende skrywers se pogings om die aard van die post-Koue Oorlog-era en wat dit beinvloed, te beskryf. Daar blyk egter eenstemmigheid te wees oor 'n aantal kenmerke.

Die post-Koue Oorlog-era word gekenmerk aan die globalisering van kapitaal, arbeid en markte, met 'n ineengeweefde wêreldekonomie wat gekenmerk word aan die bestaan van ekonomiese netwerke wat oor tradisionele staatsgrense strek. Produsente en werkers se verbintenis met hul eie state neem af. Hierdie afname is gekoppel aan die uitbreiding van die omgewings waarbinne eie belang bevorder word, met die gepaardgaande fokus op trans-nasionale organisasies. ${ }^{21}$ Veral opmerklik is die belang van regionale interafhanklikheid in die post-Koue Oorlog-era in kontras met die kunsmatige groeperings van die Koue Oorlog. ${ }^{22}$

Die toenemende bevolkingsgroei, die groeiende kompleksiteit van die organisatoriese segmente van gemeenskappe, die globalisering van nasionale ekonomieë, druk wat ervaar word weens toenemende tegnologiese ontwikkelings (soos die internet) en die druk van sub-nasionale groepe vir groter outonomiteit, is enkele van die faktore wat state se agendas kompliseer. Nasiestate beskik nie altyd oor die will, bevoegdheid en hulpbronne om hierdie uitgebreide agenda te hanteer nie. Die toenemende vermoë wat trans-nasionale en sub-nasionale akteurs demonstreer om probleme aan te spreek wat voorheen die domein van die staat was, lei daartoe dat inwoners van state toenemend hul verwagting op hierdie strukture plaas. ${ }^{23}$ Mandel beskryf hierdie verskynsel soos volg:

"What is occurring is not that the nation-state is ceasing to function or even fading away, but rather that other forces are usurping many of the traditional roles of government." 24

Die veranderinge in die geopolitieke samestelling van die wêreld met die beeïndiging van die Koue Oorlog, het kommunistiese beheer oor baie state beeïndig. Dit het saamgeval met 'n hernieude verskyning nasionalisme en verspreiding van demokrasie wêreldwyd. Sogenaamde 'people power' en 'n verspreiding van en klem op menseregte is belangrike konsepte in die moderne samelewings. Die term nasie word toenemend meer in etnies-linguistiese terme in stede van populêre soewereiniteit gedefinieër - met die gepaardgaande potensiaal vir konflik. ${ }^{25}$ Subgroepnisme lei toenemend tot groter fragmentering van moderne samelewings. Sub-groepnisme verwys na die diepe affiniteit wat mense het vir assosiasies, organisasies en sub-kulture waaraan hul histories, professioneel, ekonomiese, sosiaal en polities gekoppel is en waaraan die hoogste prioriteit verleun word. ${ }^{26}$

Mandel wys daarop dat 'n wyer spektrum van konflikvorme hul verskyning in die post-Koue Oorlog-era gemaak het. Dit blyk die gevolg te wees van die opkoms van nasionalisme en die afname in die vermoë van die nasiestaat. Dit word gesteun deur die 


\section{Esterhuyse}

afname in die nut van militêre mag - beperkings op vermoënde state se gebruik daarvan en die moontlikheid van 'n kernoorlog. Ook moet dit gesien word in samehang met die opkoms nie-tradisionele en onvoorspelbare vorme van konflik. Die Koue Oorlog idee van afskrikking "seems destined to decline (in effectiveness as well as use) both as a broad strategic doctrine and as a specific means to prevent or end conflict."27

Veiligheidsaangeleenthede wat buite die jurisdiksie van state en hul diplomatieke instellings val is aan die toeneem. Probleme wat verband hou met omgewingsbedreigings, misdaadprobleme (veral wat dwelms betref), terrorisme, vigs en vlugtelinge blyk in hierdie kategorie te val. Aan die een kant het hierdie probleme die belang van die staat beklemtoon as die enigste instelling wat werklik hierdie probleme kan aanspreek, al is dit ook deur trans-nasionale samewerking wat, net soos interstaatlike konflik, deel is van die internasionale politiekedinamika. Daarteenoor het hierdie uitdagings nuwe trans-nasionale strukture en organisasies tot stand gebring wat, op hul beurt, weer ' $n$ uitdaging is vir die bestaan van die staat. ${ }^{28}$

Die tweede faktore wat 'n definitiewe impak op die strategiese denke in die postKoue Oorlog-era tot gevolg het, was die aard, oorsake, verloop en gevolge van die 1991 Golf Oorlog. Irak se besetting van Koeweit, die wêreld se bykans eenparige veroordeling van Irak se optrede en die oorlog wat, onder leiding van die enigste oorblywende supermoondheid, daaruit vootgevloei het, was saam met die val van die Berlynse Muur, die mees opvallende bewys van 'n nuwe wêreldorde. Dit het 'n nuwe era van strategiese denke ingelei. Die Golf Oorlog het enersyds die verwagting geskep van 'n internasionale sisteem "based on norms, administered by international institutions, and resting on the commitment of leading states to the maintenance of peaceful international relations." 29 Andersyds het dit tot 'n totale herbesinning oor die aard en vermoë van militêre mag aanleiding gegee. Hierdie faktor het veral 'n rol gespeel in die aard van strategiese denke in die wêreld se enigste oorblywende supermoondheid. Freedman, met verwysing na die VSA se ervarings in Viëtnam en die Golf Oorlog, beskryf hierdie situasie soos volg:

"Up to 1991, the US seemed to have lost its grip on the art of war; after Desert Storm, it appears unbeatable." ${ }^{30}$

Die derde faktore wat 'n definitiewe impak op die aard van strategiese denke tot gevolg gehad het, is 'n definitiewe uitbreiding van en klemverskuiwing in die veiligheidsagenda: vanaf 'n kompeterende militêr-gedefinieërde siening van veiligheid, wat kenmerkend was van die Koue Oorlog-era, na 'n samewerkende benadering tot veiligheid met die klem op die nie-militêre dimensies van veiligheid. Hierdie meer holistiese en geïntegreerde benadering tot veiligheid word op verskeie wyses beklemtoon. Chipman argumenteer byvoorbeeld dat dit in die post-Koue Oorlog-era nie meer moontlik is om te onderskei tussen binnelandse en internasionale veiligheid nie. ${ }^{31}$ Die staatsveiligheids- en militêr-gedefinieërde benadering tot veiligheid het plek gemaak vir 'n meer inklusiewe definisie wat enersyds ook sub-nasionale en trans-nasionale aspekte insluit en andersyds die fokus plaas op politieke, ekonomiese en omgewingsfaktore. Hierdie siening het veral beslag gekry na die verskyning van Buzan ${ }^{32}$ se boek "People, State and Fear" in 1991. Hierdie verandering het in die post-Koue Oorlog-era tot die opkoms van sogenaamde veiligheidstudies aanleiding gegee. Dit word veronderstel dat hierdie benadering meer inklusief is as die strategiese studies paradigma van die Koue Oorlog-era en dat strategiese studies slegs een van die komponente van veiligheidstudies is. 


\section{Die aard van strategiese denke in die post-Koue Oorlog-era}

Faktore wat volgens Gray $^{33}$ die aanvanklik strategiese agenda tydens die postKoue Oorlog-era bepaal het, het die volgende aspekte ingesluit:

- Die VSA as oorblywende supermoondheid se rol as bewaker van globale orde;

- Die toenemende regionale wanorde en kultureel-politieke disharmonie;

- Die verandering van Koue Oorlog alliansies;

- Die geo-strategiese onttrekking van die VSA uit Eurasië;

Soos die post-Koue Oorlog-era egter gestalte gekry het, het verskeie nuwe aspekte op die agenda verskyn wat deur strateë wêreldwyd geargumenteer word. Enkele van hierdie aspekte word uitgelig. Hierdie is egter nòg 'n volledige lys nòg 'n aanduiding van prioriteit.

\subsection{Die veranderde aard van die bedreiging}

In die afwesigheid van 'n bedreiging van Sowjet-geïnspireerde aggressie, het Westerse regerings met die probleem begin worstel van die waarskynlikste bedreiging wat hul in die gesig staar en hoe hierdie bedreiging hanteer gaan word. Sonder enige duidelike riglyne om te volg, het langtermyn beplanning die prioriteite en probleme van die oomblik begin weerspieël. Dit het gelei tot ' $n$ aanvaarding dat konflik toenemend meer regionaal van aard sal wees. Regional probleme het meestal 'n sosio-ekonomiese oorsprong. Binne die konteks van die kompleksiteit van die post-Koue Oorlog-era is die voorkoms en aard van hierdie probleme baie moeilik om te voorspel en te beheer. ${ }^{34}$

Hierdie argument het die meeste Westerse moondhede voor die probleem van militêre inmenging in regionale konflikte te staan gebring. Vanuit die post-Koue Oorlog strategiese literatuur is dit baie duidelik dat state worstel met die redes vir moontlike betrokkenheid, die wyses waarop ingemeng behoort te word, en die voorwaardes vir inmenging. Freedman wys daarop dat daar nie werklik 'n staat is wat met die VSA op konvensionele militêre gebied kan kragte meet nie. Dit is waarskynlik waar van die meeste ekonomies ontwikkelde Westerse state, indien hul vergelyk word met die ekonomies ontwikkelende state waar hierdie streekskonflikte heel waarskylik gaan voorkom. Die gebruik van militêre mag en inmenging by streekskonflik het vir die meeste Westerse state gevolglik 'n aangeleentheid van keuse geword. ${ }^{35}$

Hierdie keuse het die aandag op twee belangrike aspekte van die post-Koue Oorlog strategiese agenda geplaas: die bedreiging wat wapens van massa vernietiging inhou en die moontlikheid van a-simmetriese konflik. Vanuit die Westerse oogpunt word gepoog om die rol van kernwapens as 'n faktor in internasionale politiek te marginaliseer - selfs te elimineer. Die moontlikheid dat state soos Noord-Korea en Irak moontlik kerntegnologie en -kennis van die voormalige Sowjet-Unie ontvang het, het verseker dat die gevare van kernprolifirasie deel van strategiese agenda bly. Dit is egter aangevul deur die massavernietigingsgevaar wat chemiese en biologiesewapens inhou. Gegewe die finasiële en tegniese vereistes, is die kanse gering dat nie-staatlike akteurs soos terroristegroepe en kriminele, kernwapens sal bekom. Chemiese en biologiese wapens mag in hierdie opsig egter meer toeganklik. Vir die meeste Westerse state, veral die 
VSA, is hierdie bedreiging en hoe om dit teen te staan, 'n baie belangrike aspek van die post-Koue Oorlog strategiese agenda. ${ }^{36}$

\subsection{Die Rewolusie in Militêre Aangeleenthede (RMA)}

Die idee van 'n rewolusie in militêre aangeleenthede, tesame met die idee van 'n informasie-oorlog, het 'n fokuspunt geword op die strategiese-agenda na die 1991 Golf Oorlog. Tot 1990 was daar 'n gebrek aan getuienis rakende hoe nuwe informasietegnologie en konsepte in die praktyk beslag sal vind. ${ }^{37}$ Die idee van 'n RMA kan na Sowjet geskrifte van die 1970's en 1980's teruggevoer word. In die VSA is dit aanvanklik as 'n 'military-technical revolution' beskou. Sò 'n beperkte benadering het ' $n$ baie noue fokus op tegnologie gehad en het nie voorsiening gemaak vir die konsepte en organisasies wat daarmee in verband staan nie. ${ }^{38}$ 'n RMA word beskou as 'n vinnige radikale toename in die effektiwiteit van militêre mag wat die aard van oorlog en die strategiese omgewing verander. Dit is die gevolg van onderlinge en ineengeweefde veranderinge in tegnologie, konsepte en organisasies. ${ }^{39}$

Daar is veral twee post-Koue Oorlog tendense wat tot 'n klem op die RMA aanleiding gegee het. Die eerste is kleiner magstrukture en begrotings sonder die gepaardgaand afname in operasionele verantwoordelikhede van weermagte in die postKoue Oorlog-era. Die RMA voorsien 'n moontlike oplossing vir die gaping wat tussen verantwoordelikhede en middele ontstaan het. ${ }^{40}$ Die tweede faktor is die problematiek van moderne demokratiese state met die aanwending van militêre mag. Hierdie probleem het sy oorsprong in verskeie aspekte:

- 'n Groter nasionalisme en weerstand by mense in arm en swak state. Die Amerikaanse ervaring in Viëtnam en Somalië getuig hiervan.

- Die onsekere en moontlik negatiewe effek wat die gebruik van mag op ekonomiese oogmerke van state kan hê. Die ontwrigting van markte en kapitaalvloei is 'n belangrike koste om te oorweeg.

- Die binnelandse mening teen moontlike ongevalle - burgerlik en militêre wat militêre optrede tot gevolg kan hê. Hierdie faktor het nuwe stukrag verkry met die toenemende verspreiding van demokrasie, synde dit makliker is om hierdie faktor te ignoreer in outoritêre state. ${ }^{41}$

- Die koste verbonde aan die voer van militêre operasies. Die Amerikaanse Weermag kan nie die risiko bekostig om 'n duur magsinstrument soos 'n vliegdekskip te verloor in 'n minder belangrike militêre operasie nie - ten spyte daarvan dat die kanse daarvoor baie skraal is!

In hierdie opsig word gehoop dat die RMA met 'n oplossing vorendag sal kom wat die aanwending van mag meer aanvaarbaar sal maak vir moderne samelewings: diskriminerend in gebruik en beperkend in ongevalle. ${ }^{42}$ Die VSA se gebruik van presisielugaanvalle in Kosovo in 1998, in stede van 'n grondoffensief, is 'n duidelike manifistasie van hierdie neiging. Besprekings rakende langafstand presisie-aanvalle, selfaangedrewe wapentuig, die gebruik van lae sigbaarheidstegnologie (stealth) en verbetering in informasie- en sisteemtegnologie vir vinnige akkurate besluitneming verskyn in baie strategiese literatuur. 
Die idee van ' $n$ informasie-oorlog word dikwels met die RMA in verband gebring - nie dat informasie nie nog altyd belangrik was in oorlog nie! Die RMA word egter gedryf deur 'n groot toename in die kwaliteit en kwantiteit van informasie wat deur die gebruik van rekenaar-tegnologie vir insameling, verwerking en verspreiding van informasie beskikbaar gestel word. Baie word deur strateë geskryf rakende die effek wat hierdie toename in kwaliteit en kwantiteit van informasie tot gevolg sal hê. ${ }^{43}$

\subsection{Veranderde rol en aard van gewapende magte}

Een van die mees opvallende aspekte van post-Koue Oorlog strategiese denke is die vrae wat geopper word rakende die veranderde aard van gewapende magte en hul aanwending. Dit sal nie moontlik wees om al die aspekte wat in hierdie verband ter sprake is uit te lig en te bespreek nie. Enkele van die aspekte ter sprake sluit in:

- Die problematiek van a-simmetrie wat statutêre militêre magte moontlik op die slagveld in die gesig staar;

- Die belangrikheid van gesamentlike (joint) en geallieerde of koalisieoperasies.

- Die benutting van konvensionele magte in vredesoperasies en, wat die VSA na verwys as 'Operations Other Than War (OOTW)';

- Die 'privatisering' van veiligheid;

- Nie-offensiewe verdediging.

Die idee van a-simmetrie het veral in die VSA beslag gekry. Die VSA, en die meeste Westerse moondhede, aanvaar dat hul potensiële opponente nie dieselfde wetenskaplike en tegnologiese hulpbronne tot hul beskikking sal hê nie. Daar word gevolglik na ander teenwigte gesoek waardeur die koste van die konflik verhoog kan word tot op die punt waar Westerse besluitnemers lamgelê word. Een voorbeeld hiervan is die sogenaamde 'Somaliese strategie' waarin 'n relatief klein groepie vegtendes met lae koste wapentuig binne 'n stedelike omgewing tussen burgerlikes opereer. 'n Ander moontlikheid is die gebruik van terrorisme, moontlik wapens van massavernietiging, teen 'sagte' teikens om die gebruik van militêre mag deur Westerse moondhede af te skrik. ${ }^{44}$ Hierdie probleem herinner baie sterk aan die problematiek van teen-insurgensie wat state in die Koue-Oorlog mee geworstel het.

Die voorbeeld van die Golf Oorlog, die groter samewerking tussen state in die post-Koue Oorlog-era, ook op militêre gebied, en die toename in vredes- en humanitêre operasies, het dit vir state bykans onmoontlik gemaak om op hul eie operasies uit te voer. Dit het die idee van geallieerde en koalisie-operasies weer nuwe stukrag gegee. Hierdie hernieude fokus moet voorts gesien word teen die agtergrond van die beweging na groter gesamentlikheid tussen weermagsdele binne weermagte wêreldwyd. Hierdie beweging het sy oorsprong as een van die belangrikste regstellings wat die Amerikaanse weermag deurloop het na die Viëtnamese Oorlog en die debakel rondom die bevryding van die Amerikaanse Gyselaars in Teheran. Dit het formeel beslag gekry deur die goedkeuring van die Goldwater-Nichols Wetgewing deur die Amerikaanse Kongres in $1986 .{ }^{45}$

Vredesoperasies, spesifiek die rol wat konvensionele magte in die verband vervul, het ' $n$ belangrike besprekingspunt op die strategiese agenda in die post-Koue Oorlog-era 


\section{Esterhuyse}

geword. Die fokus is verskuif vanaf militêre operasies as 'n middel tot 'n beter vrede, na die gebruik van sodanige magte om vrede te handhaaf wat waarskynlik deur middel van 'n politieke proses beslag gekry het. Post-Koue Oorlog strategiese literatuur word gekenmerk deur 'n fokus op en prominensie van vredesoperasies en wat daarmee verband hou.

Die veranderde rol van gewapende magte het ook die fokus na die toenemende gebruik van privaat veiligheidsmaatskappye verplaas. Eendersyds het hierdie maatskappye beslag gekry as gevolg van die afskaling van gewapende magte wêreldwyd. Andersyds vloei dit voort vanuit die teenkanting wat state ervaar teen die aanwending van hul gewapende magte. Die fokus op hierdie fenomeen in die strategiese literatuur hou eerstens verband met vrae rakende die etiese aspekte in die aanwending van privaat veiligheidsmaatskappye en tweedens die werklike nut van hierdie maatskappye.

Strategiese denke rakende nie-offensiewe verdediginging fokus op die vraag hoe verdediging gereël moet word sodat dit nie deur ander as 'n bedreiging ervaar sal word nie. Die sentrale gedagte is dat verdediging van state op so 'n wyse ge-organiseer moet word dat dit nie vir moontlik is om offensiewe operasis uit te voer anders dan wat nodig is om die staat se eie grondgebied, kuswaters en lugruim te verdedig nie. In seker opsigte verteenwoordig dit, net soos die denke rakende beperkte oorlog tydens die Koue Oorlog, 'n rewolusie in strategiese denke, synde dit 'n verskywing van die tradisionele strategiese studies paradigma vereis. Butfoy argumenteer dat nie-offensiewe verdediging nie net 'n verandering van strategiese denke vereis nie, maar ook wat die strategiese beplanning en organisering betref. ${ }^{46}$

\section{Samevatting}

Strategiese studies het tydens die Koue Oorlog ' $n$ vaste agenda gehad. Strategiese denke tydens hierdie era was gefokus. Enersyds het die aard van die bedreiging wat bestaan het, denke gefokus en in ' $n$ sekere opsig ' $n$ raamwerk vir strategiese denke verskaf. Ook het dit bygedra tot ' $n$ mate van sekerheid: die bedreiging was bekend en daar kon vir 'n spesifieke strategiese scenario en bedreiging voorberei word. Andersyds het die aard van die middele wat beskikbaar was die strategiese debat oorheers. Met die aanvang van die Koue oorlog was daar nie ' $n$ tradisie van nie-gebruik van kernwapens nie, synde dit gebruik is in die laaste fases van die Tweede Wêreldoorlog. Strategiese denke tydens hierdie era is gevolglik tot 'n groot mate - veral tydens die aanvang van die Koue Oorlog - oorheers deur die moontlikheid van 'n kernoorlog.

In teenstelling hiermee is die strategiese agenda tydens die Koue Oorlog oorheers deur die Sowjet-Unie se gebruik van sogenaamde 'proxy wars' om die ideologie van kommunisme te versprei. Dit het saamgeval met die era van dekoloniesasie. Hierdie faktore het verseker dat denke rakende insurgensie en teen-insurgensie ' $n$ prominente posisie op die strategiese agenda tydens die Koue oorlog geniet het. Dit is aangevul deur die idee van beperkte oorlog as middel om kommunistiese uitbreiding te stop en kernafskrikking te verbeter.

Die 1991-Golf Oorlog wat die post-Koue Oorlog-era ingelei het, het ' $n$ nuwe dimensie tot strategiese denke toegevoeg. Dit het ' $n$ strategiese era ingelei wat gekenmerk word aan 'n onvoorspelbare komplekse aard en "n fokus op veiligheidseerder as strategiese studies. Die VSA as oorblywende supermoondheid gee die pas aan 


\section{Strategiese denke}

wat strategiese denke in die post-Koue Oorlog-era betref. Dit is gevolglik verstaanbaar dat aspekte soos die RMA, a-simmetriese konflik, die komplekse bedreigingsomgewing, nie-offensiewe verdediging ens prominent op die strategiese agenda figureer. Dit is duidelik dat daar geen vaste en maklik identifiseerbare agenda vir strategiese denke in die post-Koue Oorlog-era is nie. Post-Koue Oorlog strategiese denke word daarom gekenmerk aan die kompleksiteit en uiteenlopende aard daarvan.

Die meest uitstaande verskil tussen die Koue oorlog en post-Koue Oorlog strategiese denke is die beperkte en gefokusde aard van Koue Ooorlog denke in teenstelling met diè in die post-Koue Oorlog-era. Die oorsprong daarvan moet aan die onderskeie bedreigings in die verskillende eras toegeskryf word. Die Koue Oorlog bedreiging is hoofsaaklik in magsterme - veral militêre magsterme - gedefinieer, in teenstelling met post-Koue Oorlog bedreigings wat hoofsaaklik in nie-militêre en magsterme gedefinieer word nie.

\footnotetext{
Brzezinski, Z. 1991/92. "The Consequences of the End of the Cold War for International Security." Adelphi Paper 265. The International Institute for Strategic Studies. p. 4.

2 Ibid., p. 5.

3 Ibid.

4 Carl von Clausewitz. 1976. On War. Translated by Howard, M and Paret, P. New York: Princeton. p. 578

5 Gray, C.S. 1999. Modern Strategy. New York: Oxford University Press. p. 125-126.

6 Richardson, J. 1999. "Strategic Thinking in an Era of Intervention: Thinking out of a Box with No Sides." Comparative Strategy. Vol 18, no 1. p. 32.

$7 \quad$ Gray, op. cit., p. $9 \& 37$.

Nye, J.S. 1991/92. "The Contribution of Strategic Studies: Future Challenges." Adelphi Paper 265. The International Institute for Strategic Studies. p. 20.

Thatcher, M. 1999. "Deterrence Is Not Enough: Security Requirements for the $21^{\text {st }}$ Century." Comparative Strategy. Vol 18, no 3. p. 216.

Brodie, B. 1973. War and Politics. New York: Macmillan Publishing. p. 62.

Ibid., p. 70.

Strachan, op. cit., p. 191.

Williams, P. 1987. "Nuclear Deterrence." In Baylis, J. et al. Contemporary Strategy: Theories and Concepts. London: Holmes \& Meier. p. 115.

Ibid., p. 117-121.

McInnes, C \& Sheffield, G.D. 1988. Warfare in the Twentieth Century. London: Unwin Hyman. P. 207.

Thatcher, op. cit., p. 216.

Sien Bernard Brodie se bespreking van Korea as die eerste beperkte oorlog in die verband. Brodie, op. cit., p. 63.

Garnett, J. 1987 "Limited War." In Baylis, J. et al. Contemporary Strategy: Theories and Concepts. London: Holmes \& Meier. p. 190.

Keel, E.E. 1992. "Toward A New National Defense Strategy: Policing the Battlefields of the Cold War." Comparative Strategy. Vol 11, no 4. p. 371.

Rosenau, J.N. 1995. "Security in a Turbulent World." Current History. Vol 94. No 592. p. 197.

Mandel, R. 1999. The Changing Face of National Security: A Conceptual Analysis. London: Greenwood Press. p. 5.
} 


\section{Esterhuyse}

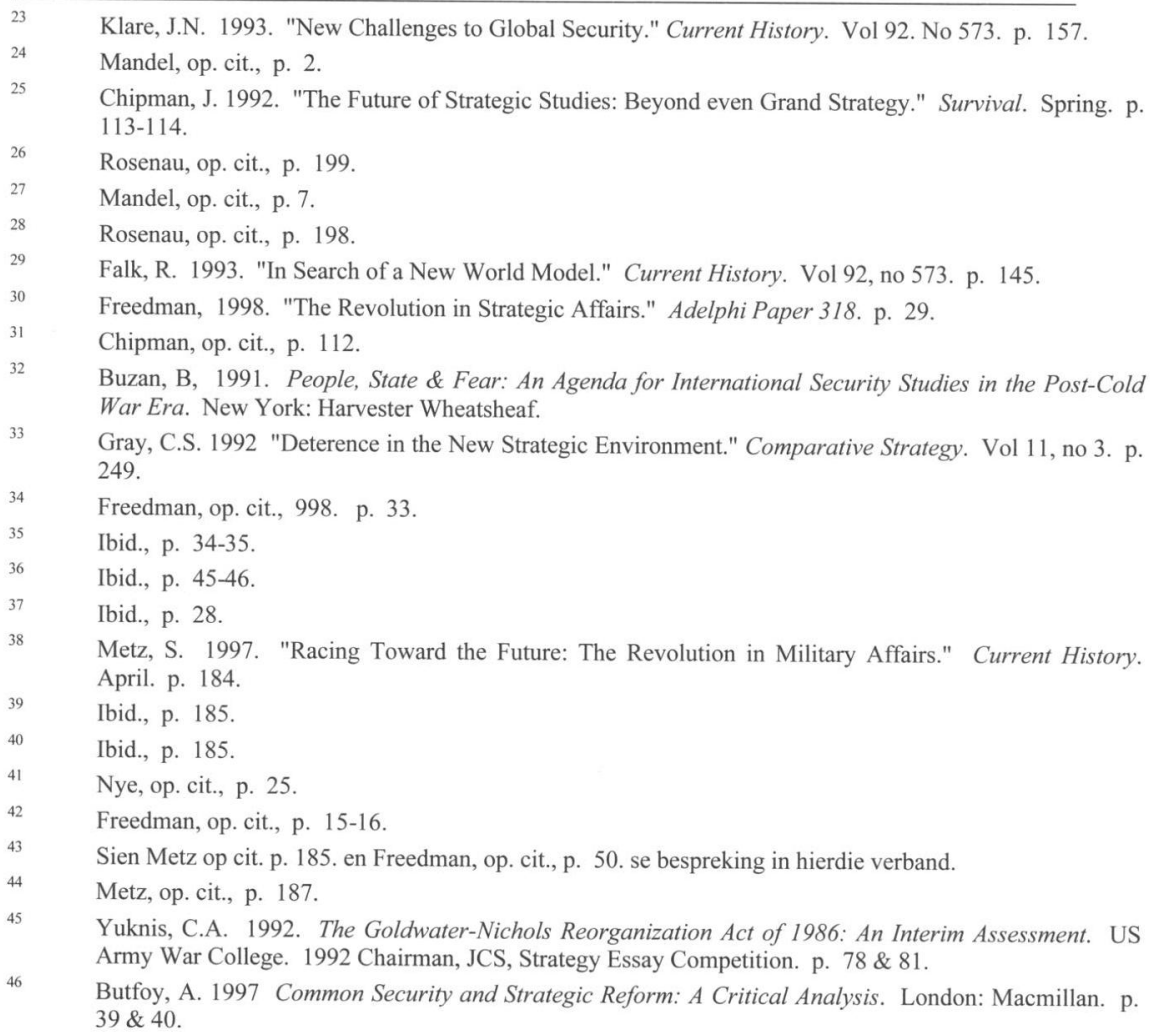

